Maurice Hilleman (Director of the Merck Institute for Therapeutic Research) has had an unprecedented and fruitful career in the field of biomedical research. He is recognized as having developed more vaccines than any other person and in so doing has had a tremendous impact on world health. It was at our request that he presents a personal account of the development of vaccines that were a large part of his career in basic and applied research-a career that has spanned spanned more than half a century.

\title{
Six decades of vaccine development—a personal history
}

\section{Historical beginnings}

The sciences of vaccines and immunology ${ }^{1}$ were created by Jenner in $1796^{2}$ in

\section{MaUrice R. Hilleman}

Army Institute of Research in Washington, DC. Joining J. Smadel's Virus and Rickettsial Disease staff at Walter Reed provided an exceptional opportunity to follow the workings of the wartime Commissions of the Armed Forces Epidemiological Board. I also witnessed the evolution of the program of the National Foundation for Infantile Paralysis to develop killed and live poliomyelitis vaccines, made possible by using cell culture and setting the stage for a new era of vaccines.

Basic influenza. My principal assignment at Walter Reed was to study respiratory illnesses of military significance and to devise a science and a strategy for averting the "next influenza pandemic," the last of which had been "Spanish influenza" of 1918-19 (subtype H1), and that killed 20-40 million people worldwide. In this quest, I served as the central laboratory for worldwide military influenza surveillance. The failure of protection of the influenza vaccine of 1947 indicated antigenic change in the virus and prompted the need to prepare antisera against a large number of past and contemporary influenza isolates to carry out comparative strain analyses between vaccine and circulating viruses. Chicken antis$\mathrm{era}^{9}$ were found to be highly specific and reproducible in defining immunologic specificity of the immunogenic viral surface hemagglutinin that is the principal viral element in stimulating immunity.

In cross-matching tests there was a startling revelation ${ }^{10,12}$; influenza $\mathrm{A}$ Jenner and the first vaccine trial. cellular microbes, now classified Chlamydiae, but formerly considered to be viruses.

Grounded in the basic and theoretical, it seemed timely to pursue the practical during a four-year tenure in the Virus Laboratories of E.R. Squibb and Sons of New Jersey. Japanese B encephalitis vaccine (see Table) was urgently needed for protecting the troops in the World War II Pacific offensive. Reviewing a publication by A. Sabin ${ }^{6}$ made it possible to develop a workable process for making a safe and effective inactivated mouse brain vaccine against Japanese $B$ encephalitis and to begin delivery to the military of large amounts of vaccine a few months later. Working with W. Stanley and C. Nigg, a commercial process was evolved for efficient manufacture of W. Stanley's Sharples centrifuge-purified influenza vaccine that became the paradigm for quality influenza vaccine production of the time. Continuing studies ${ }^{7,8}$ of the Chlamydiae revealed a diversity of chemical composition that showed them to be obligate intracellular parasites of greater complexity than that of viruses.

I left Squibb in 1948 to engage in research at the Walter Reed viruses recovered in successive years showed gradual and progressive minor antigenic changes punctuated infrequently by major changes ${ }^{13}$. The validity of these findings was confirmed in prospective and retrospective seroepidemiologic analyses ${ }^{14}$ using human sera. Such patterns of antigenic change (see review ${ }^{13}$ ) are now called drift and shift ${ }^{15}$. The findings set the stage for rapid detection ${ }^{16}$ of viruses having major antigenic difference for which the population was inexperienced and which could cause major epidemics or pandemics.

Pandemic influenza. The payoff of the concepts and findings developed during the previous seven years came in 1957 when I noted a report in the April 17 New York Times of the occurrence of epidemic febrile respiratory illness in infants in Hong Kong. The occurrence had not been detected by the worldwide influenza surveillance systems of the time. Testing of viral specimens from patients and extensive strain analyses with human and animal sera provided definitive evidence that the new 


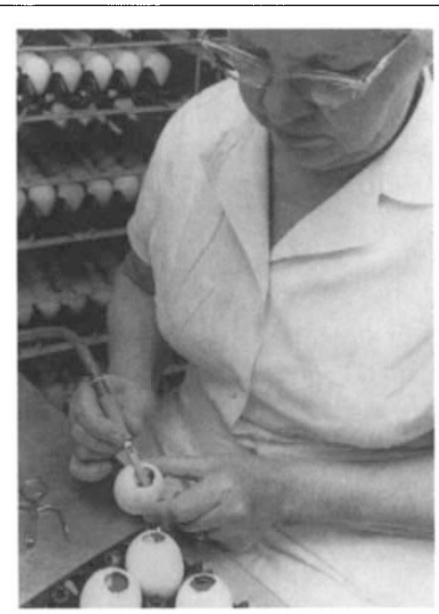

Harvesting influenza virus. virus $^{16}$ (called Far East and later Asian influenza) was quite different from any previous influenza $A$ virus. The academic, governmental and industrial scientific communities and the wire services were alerted and given the prediction $^{16,17}$ that a pandemic of influenza would ensue in the US beginning in the fall with the start of school. It did occur ${ }^{17}$. Early availability of the new and different virus allowed manufacturers to prepare 40 million doses of vaccine $e^{17,18}$ (see Table) that were available for immunization before the late November peak of the pandemic in the US, saving tens of thousands of lives. The early request to the manufacturers to save the roosters (that would otherwise have been slaughtered), needed to assure an adequate supply of fertile eggs, was critical to the volume of vaccine that could be made. Retrospective studies indicate that the 1957 Asian influenzae A (subtype H2) occurrence was the second true pandemic of this century. The Hong Kong virus of 1968 (subtype H3) was the third ${ }^{15}$.

Adenoviruses. It is true in science that some of the most important discoveries are the product of error or tactical misfortune. So it was with the discovery of the adenoviruses. I had organized an expedition to Ft. Leonard Wood ${ }^{19}$, Missouri, in 1953, to collect throat washings en masse from influenza patients that would provide native virus needed to compare with egg passage virus to determine whether there was significant antigenic change during chick embryo propagation ${ }^{13}$. It was ultimate good fortune that the cause for the epidemic had changed by the time our team arrived at the study site and influenza was no longer present ${ }^{19}$.

The possible personal consequences of a flawed and expensive expedition was recognized and the logic for extrication, in this instance, seemed to be to search for the cause of the second respiratory disease, then of unknown etiology. Application of explant tissue culture was tried. Unexpectedly, a trachea obtained at autopsy from a newly succumbed patient at the hospital at Walter Reed became available and explant cultivation of tracheal epithelium provided small sheets of ciliated cells. Inoculation with patients' throat washings ${ }^{20}$ resulted in recovery of several strains of a virus that caused grapelike cytopathic changes and that were serially cultivable on passage. Human autopsy tissues to prepare additional explant cultures were not available, but rapid rescue of the new discovery was made by applying J. Syverton's newly

Live

Measles More Attenuated

Mumps

Rubella

Measles-smallpox

Mumps-rubella

Varicella evolved roller tube cultures of HeLa cells. Details of the preliminary work with tracheal explant cultures were not published. With the availability of virus and cells ${ }^{20}$ and with the development of tests for neutralizing and complement-fixing antibodies ${ }^{20,21}$, it was possible to perform diagnostic tests and to relate the virus to the clinical illness ${ }^{20-22}$, to define the clinical picture in laboratory-defined cases $^{22}$ and to describe the epidemiol$\mathrm{ogy}^{23}$ of the very serious disease entity previously known to the military as acute respiratory disease (ARD) and primary atypical pneumonia (PAP) of new recruits. The biology of the virus was defined ${ }^{24,25}$ and three distinct serotypes were recognized (types 3,4 and 7) ${ }^{26}$. Rowe and Huebner ${ }^{27}$, in the same time period, reported recovery of latent viruses from tonsils and adenoids of children. It was shown in joint studies that the two sets of viruses belonged to the same family and the agents called RI and APC viruses were renamed adenoviruses ${ }^{28}$. The serotypes from the two sources were, however, different.

Availability of virus led us to develop a formalin-killed vaccine from types 4 and 7 adenovirus grown in cell cultures of Macacus monkey kidney. Our vaccine was evaluated in a controlled study at Fort Dix, NJ, in 1956-1957 (refs. 29-31) and at Fort Leonard Wood, MO, a year later ${ }^{32}$. The vaccine proved highly efficacious in preventing infection and disease. It was remarkable in that the time from virus discovery to development and proof of efficacy of a vaccine was only three years.

\section{The move to the Merck Institute}

In 1957, Vannevar Bush, then Chairman of Merck \& Co., conceived the need for an intensive virus research initiative which I was persuaded to establish and direct, starting on New Year's Eve, 1957. It was determined that the venture which would embrace all the required basic sciences, development, engi-

Vaccine development and licensure, 1945-1996

\begin{tabular}{lr}
\multicolumn{1}{c}{ VIRAL VACCINES } \\
Vaccine & Date \\
Killed & \\
Japanese B & 1945 \\
Pandemic A2 Influenza & 1957 \\
Adenovirus & 1958 \\
Purified Poliovirus & 1960 \\
Purified Influenza & 1969,70 \\
Adjuvanted Influenza & 1973 \\
Hepatitis B & \\
Plasma-derived & 1981 \\
Recombinant & 1986 \\
Hepatitis A & 1996
\end{tabular}

BACTERIAL VACCINES AND GLOBULINS
Vaccine
$\begin{aligned} & \text { Bacterial Subunit } \\ & \text { Meningococcus A }\end{aligned}$
$\begin{aligned} & \text { Meningococcus C } \\ & \text { Combined }\end{aligned}$
$\begin{aligned} & \text { A-C } \\ & \text { A-C-Y-W135 }\end{aligned}$
$\begin{aligned} & \text { Pneumococcus } \\ & \text { 14 types }\end{aligned}$
$\quad 1974$
23 types
$\begin{aligned} & \text { H. Influenzae } \\ & \text { Conjugate }\end{aligned}$

Edmonston B + Gamma Globulin 1963

1968

1969

Combined live vaccines

Measles-rubella $\quad 1971$

Measles-mumps 1973

Measles, mumps, rubelia (MMR) 1971

1995

Marek's Disease (cancer of chickens)

1971,75

improved vaccines are not included here.

*Made possible by early detection, analysis and distribution of the virus to the manufacturers. 
Hurdles encountered and surmounted on the road to sophistication in vaccine development

- Judgmental determinations in absence of defined knowledge.

- Lack of animal models forced early clinical studies in man.

- Achieving participation with informed written consent.

- Non-availability of propagation systems.

- Safety in propagation systems - undetectable indigenous contaminants and non-target effects.

- Evolvement of best possible preclinical tests.

- Monitored clinical probes, freedom from transmission to contacts, and proof of prophylactic efficacy.

- Achievement of appropriate balance in immune responses, lack of adjuvants other than alum.

- Markers of protection and achieving of durable immunity.

- Product stabilization during storage and distribution.

neering, data analysis and government liaison. Importantly, clinical research was included as a major part of the central departmental responsibility and far-reaching and productive relationships were established with the Children's Hospital of Philadelphia and the Department of Pediatrics of the University of Pennsylvania, and with the Louisiana State University International Center for Medical Research and Training in Costa Rica.

It was of substantive importance that the departmental vaccine enterprise was amply supported by Merck even though patent protection for vaccines was poor and biological products became generic when essential private discoveries were disclosed in the regulatory control standards prepared by the government licensing authority. There was little chance to protect intellectual property rights other than by preservation of proprietary know-how. Copying by others was simple and pricing would reflect the

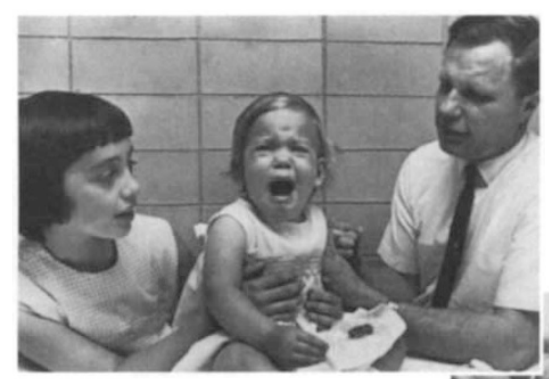

Above, Jeryl Lynn persuades little sister Kirsten Jeanne to volunteer for experimental mumps vaccine. Right, Harvesting embryos from duck eggs.

lack of large research

investment by those who did little or no research.

Basic understanding of viruses and vaccines was poorly evolved by 1957 and the vaccine research undertaking at Merck in its early years was driven largely by empiricism, trial and error and exercise of judgment. By 1984, concepts and sophisticated procedural technologies had been developed for three additional vaccines for which initial clinical trials had been carried out. These were the experimental hepatitis A, varicella and coupled Haemophilus influenzae vaccines.

The first-generation vaccines (Table) fall into three groups: live and killed virus, and subunit bacterial vaccines. Two standardized immune globulins were also developed. This work highlighted common elements and hurdles that needed to be crossed in developing vaccines.

\section{Live virus vaccines}

The era for live virus vaccines was made possible by the breakthrough cell culture technology of Enders, Weller and Robbins ${ }^{3}$, which opened the way to the first vaccines against poliomyelitis (see historical review ${ }^{33}$ ).

Measles vaccine. The Enders group soon grew Edmonston B measles virus in chick embryo cultures and carried out clinical probes ${ }^{34,35}$. The virus produced rash, fever and malaise of such intensity as to preclude acceptability for routine vaccination in $\operatorname{man}^{36}$. The development of a useable measles virus vaccine $^{36-39}$ lay in (a) eliminating chicken leukemia virus that was ubiquitously present; (b) reducing the excessive clinical virulence of the virus; (c) conducting very large clinical studies (about 20,000 children) to certify the safety of the virus and the vaccine from the regulatory standpoint; (d) establishing the protective efficacy of the vaccine in placebo-controlled clinical trials; (e) determining a suitable age for routine administration when maternal antibody was lost. The leukemia hurdle was solved by acquisition of a newly evolved flock of leukemia-free chickens ${ }^{40}$ and the virulence problem found solution initially by coadministration of measles immune globulin of appropriately standardized potency ${ }^{37,39}$. Later, the more attenuated (Moraten line) ${ }^{41}$ version of the virus was developed and proof of efficacy was established in placebo-controlled clinical studies ${ }^{38,40}$. Measles vaccines licensed to others at the time were withdrawn by the regulatory authority because of excessive reactogenicity (dog kidney-grown) and because a killed virus vaccine caused serious delayed hypersensitivity-like reactions following exposure to measles virus, in nature, about a year after vaccination.

Mumps vaccine. Successful development of the measles vaccine prepared the way for mumps. A strain of mumps virus was recovered in embryonated hens' eggs from throat washings of patient Jeryl Lynn ${ }^{42}$ (my daughter). Experimental vaccines made from Jeryl Lynn virus at different passage numbers in chick embryo cell culture were tested clinically ${ }^{43}$ and a level was found that induced sufficient antibody without detectable reactogenicity. Placebo-controlled clinical trials ${ }^{44,45}$ in children established protective efficacy and licensure was granted in 1967 following large-scale safety trials.
Rubella vaccine. Following discovery ${ }^{46,47}$ of the virus, development of a vaccine relied mainly on achieving a simple and reliable means for viral growth and attenuation. Chick cell culture did not support viral replication and it appeared that the virus might require cells from an earlier stage in embryonic development. Duck eggs require four weeks rather than the three weeks needed to hatch chicks and significant amounts of duck tissue could be harvested from early duck embryos. Whether by luck or by serendipity, duck cells did support luxuriant virus growth and rapid and reliable attenuation of rubella virus ${ }^{48}$, opening the door to a vaccine.

A large problem in determining viral attenuation arose from the lack of animal models, making it necessary to carry out all 
Common elements in evolution of vaccines

- Etiologic discovery and definition.

- Propagation in acceptable systems.

- Choice of live attenuated, whole or subunit killed approach.

- Appropriate attenuation or inactivation to achieve acceptable reactogenicity and immunogenicity.

- Formulation to achieve adjuvantation, appropriate immune response, stability and long-term immunity.

- Preclinical and subsequent clinical assessment for safety, reactogenicity, immunogenicity.

- Proof of protective efficacy and long term immunity.

- Development of surrogate markers governing acceptability for product release.

- Scale-up, licensure, manufacturing and distribution.

tests in child volunteers. The approach for rubella vaccine, as for the others, was to prepare lots of vaccine at various stages of progressive attenuation in duck cells and to work backward in clinical testing in order to achieve, in a safe way, a level of acceptable clinical reactogenicity that was still adequately immunizing. As we were developing a rubella vaccine in our laboratories using our Benoit virus isolate ${ }^{48-50}$ propagated in duck cell culture, Meyer and Parkman were testing a monkey kidney cell-passaged virus called HPV-77. We were called upon, by outside public health interests, to examine HPV-77 because it was believed that focus on a single virus would hasten development of a licensable product needed to fend off a soon-expected major epidemic of rubella and its congenital damage. The HPV-77 virus was excessively virulent for children, but five passages in duck cells provided a strain that was similar to the attenuated Benoit virus ${ }^{49,50}$. With no advantage, the duck cell modified HPV-77 vaccine was carried forward to development and, following extensive laboratory and clinical studies $^{52-55}$, licensing in 1969.

Combined measles, mumps, rubella (MMR) vaccine. Evolution of the measles, mumps and rubella vaccines provided reality for the long held dream of single dose administration of combined live pediatric vaccines. The principal hurdle was to achieve adjustment of the infectious dosages of the individual virus components in order to preclude blockade of responses through interference. MMR was licensed in 1971 and became a principal flagship for routine pediatric immunization still in use today. Combined measles-smallpox vaccines were also developed ${ }^{56,57}$ with the purpose to include measles vaccine in the worldwide program to eradicate smallpox that was being carried out at the time.

Both the individual and combined measles, mumps, and rubella vaccines have proved highly successful in long-term clinical follow-up for safety and protective efficacy (see reviews ${ }^{58,59}$ ). They have been widely applied. By 1996, more than 437 measles, 265 mumps and 349 million rubella vaccine doses had been distributed from these laboratories in single or combined formulation. Diseases caused by measles, mumps and rubella viruses have become inconsequential in the U.S. (see Bloom \& Widdus, page 480 ). Although societal benefits are the most rewarding consequence of vaccination, it is notable that use of combined MMR vaccine was estimated to have provided $\$ 5.1$ billion direct and indirect cost savings in the U.S.A. for the year 1992 alone $^{60}$.

Varicella Vaccine. Varicella (chickenpox) virus vaccine $e^{61}$ was pioneered in these laboratories in studies of our $\mathrm{KMcC}$ isolate during a period of 15 years in which more than ten individual attenuated live virus vaccines were prepared and evaluated in tests in children. Though the $\mathrm{KMcC}$ virus did not become a licensed vaccine, it did establish the principles and methodologies whereby a vaccine could be made using another strain of virus. This vaccine program was initially criticized and even condemned by a segment of the pediatric community, but persistence stayed the storm and allowed for the evolution of concepts and procedures that were needed to develop a vaccine.

The $\mathrm{KMcC}$ virus proved recalcitrant in its failure to give sufficient immune response with virus of satisfactory clinical attenuation. The successfully attenuated Japanese Oka virus ${ }^{62}$ fared better and was later used by us $^{63}$ to develop a varicella vaccine that was licensed in 1995 in the US.

Marek's Disease. Also known as range paralysis of chickens, Marek's Disease, like varicella, is caused by a herpesvirus. Unlike varicella, it causes cancer (neurolymphoma and visceral lymphoma) and lowered productivity of chickens (eggs and meat) with great economic loss to the poultry industry. The finding ${ }^{64}$ of an antigenically related turkey herpesvirus that protected chickens against Marek's disease was an outstanding breakthrough. This ended our own ongoing efforts to attenuate chicken Marek's virus in the laboratory and initiated our pursuit of the turkey herpesvirus discovery. Highly effective and very successful frozen in-

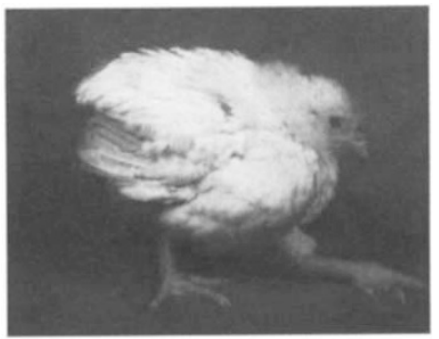
Young chicken with Marek's Disease. fected cell and purified dried virus vaccines were developed ${ }^{65,66}$ in a long and complex program ending with licensures in 1971 and 1975, respectively. The Marek's vaccine was the world's first licensed vaccine against any viral cancer and revolutionized the economics of the poultry industry.

\section{Killed virus vaccines}

Poliomyelitis vaccines. Cell culture technology opened the door to the highly successful killed Salk ${ }^{67}$ and live Sabin ${ }^{68}$ poliovaccines that were introduced in the $1960^{\prime}$ s. Our entry into poliovaccine research was in developing a highly purified poliovaccine $e^{69,70}$ of precisely standardized potency that would assure immunogenicity for all serotypes. At that time, Macacus monkey renal cells used to grow viruses for vaccines were plagued with numerous indigenous monkey virus contaminants ${ }^{71}$ that made the development of live virus vaccines all but impossible. The magnitude of the problem caused me to seek advice from William Mann, then Director of the Washington, DC Zoological Park, as to how to import monkeys from the jungle that would be free of indigenous viruses. He advised importation of Cercopithecus (green) monkeys from West Africa that were subsequently found by us to be remark-

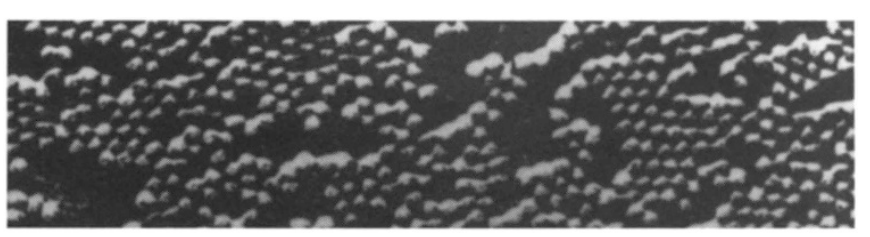

Purified polio virus 


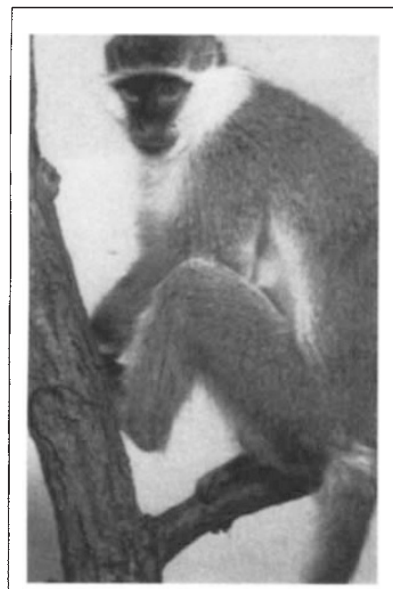

Cercopithecus monkey, ably free of indigenous viral contamination. Most importantly, the infected Cercopithecus kidney cells showed cytopathic changes when infected with then covert agents, making possible the detection of hitherto hypothetical "non-detectable viruses." One such agent was a Macacus monkey polyomavirus $\mathrm{SV}_{40}$, found to be present both in live and in killed poliovaccines $^{72-74}$. About one in 10,000 infectious particles resisted inactivation by formaldehyde. Further, the monkey virus was found to be oncogenic for newborn hamsters ${ }^{75,76}$. It provided a breakthrough ${ }^{77}$ in cancer immunology when we found that irradiated $\mathrm{SV}_{40}$ tumor cells were able to prevent tumor formation in hamsters that had been given live $\mathrm{SV}_{40}$ virus when newborn. Clean up and elimination of $\mathrm{SV}_{40}$ virus from the live and killed vaccines were simple and rapid by neutralization of the $S_{40}$ agent with homologous antibody and by substituting Cercopithecus monkey kidney cultures for vaccine production. The $\mathrm{SV}_{40}$ virus became a prime model for studies on tumor prevention ${ }^{77}$, for the discovery of the p53 anti-oncogene ${ }^{78}$ and for elucidating molecular details in viral and eukaryotic cell processes ${ }^{79}$.

Hepatitis B plasma-derived vaccine. Persons who recover from hepatitis $B$ virus infection develop antibodies against the surface antigen of the virus and it was presumed that antibody would be a reliable marker for protective immunity. Development of the plasma-derived hepatitis B vaccine was initiated in 1968 and culminated in licensure in 1981, after a 13 year-long pioneering program to evolve a safe and effective immunogen using viral surface antigen purified from the plasma of persistently infected human carriers ${ }^{80-84}$. A principal problem was to assure inactivation of residual hepatitis $B$ virus and possible other non-detectable viruses in human blood. The problem was solved by sequential application of three inactivating steps (pepsin digestion, urea denaturation and formaldehyde) each of which was sufficient to destroy all possible life forms in human blood. Importantly, urea destroyed the scrapies agent that was the surrogate for Creutzfeldt-Jacob (prion) disease. Once the processes were evolved, clinical work was conducted, and a license granted in 1981 following proof of efficacy in a placebo controlled study ${ }^{85}$. This was a seminal event since the product represented the world's first licensed vaccine for preventing human cancer as well as chronic-active viral hepatitis and cirrhosis of the liver.

Recombinant hepatitis B vaccine. Limited supply of hepatitis B carrier plasma necessitated creating an alternative source of surface antigen to make vaccine. Fortunately, the new era of genetic expression of proteins was beginning and was applied. A joint research program yielded a recombinant vector expression system ${ }^{86}$ for preparing hepatitis antigen in yeast. Development of a commercial process allowed us to substitute the recombinant for the plasma-derived antigen in the vaccine ${ }^{87-89}$. Yeast recombinant vaccine was licensed in 1986 and represented the world's first vaccine using an antigen prepared by genetic engineering.
Cancer cell-derived hepatitis B vaccine. Prior to the recombinant era, the concept had been presented ${ }^{90}$ that cancer cell-derived products would be safe if freed from all DNA. In testing the hypothesis, a large program was carried out to produce surface antigen in continuous flow hollow fiber propagators loaded with neoplastic human liver (Alexander) cells ${ }^{91}$ that secreted hepatitis $B$ antigen. The process was economically efficient and animal and human tests of vaccine made using the purified antigen gave results comparable to those obtained with plasmaderived vaccine ${ }^{91-93}$. Though the process was never used commercially, it did achieve the evolution of a system for freeing viral surface antigen from DNA and for process validation that was subsequently used in evolving concepts and rules for experimental and licensable vaccines that would ultimately be prepared using continuous cell lines and cancer cells ${ }^{94}$. (See hepatitis B reviews refs. 95-97).

Hepatitis A. Development of hepatitis $A$ vaccine was the culmination of a basic research program started in the early 1960's to discover the viruses that cause human hepatitis. The initial breakthrough came with the recovery and characterization in 1973 of the prototype CR326 strain ${ }^{98,99}$, the first human hepatitis $A$ virus, isolated from a Costa Rican patient with hepatitis A using the Deinhardt, et al. ${ }^{100}$ marmoset monkey model. It was recently found ${ }^{101}$ that Deinhardt's GB virus isolate was not hepatitis $A$, but was instead, the first example of non-A, non-B hepatitis caused by Flaviviruses, a remarkable discovery that had not been realized. CR326 hepatitis A virus-infected marmoset liver provided antigen that permitted ${ }^{102-105}$ the development of serologic tests, studies of the epidemiology of the infection and the identification of the virus as an enterovirus-like agent. Importantly, a prototype

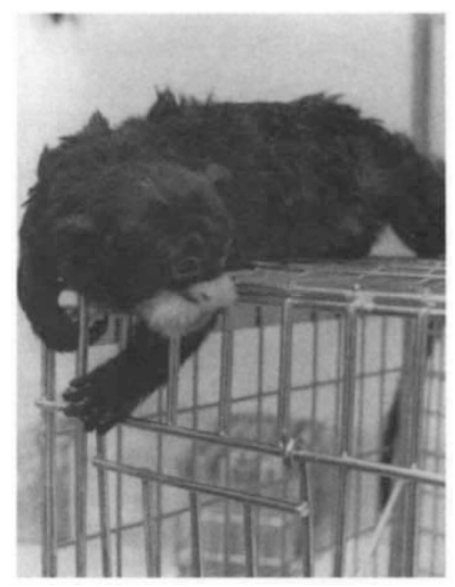

Marmoset monkey highly succeptible to hepatitis A infection. killed virus vaccine ${ }^{106}$ was evolved that was highly immunogenic and protective in marmosets and was intended to serve as the model for later killed vaccine development. The second breakthrough ${ }^{107}$ came with propagation in 1979 of hepatitis A virus in cell culture, opening the door to vaccines for man. We investigated both a highly promising live attenuated hepatitis $A$ vaccine that was tested extensively in animals and $\operatorname{man}^{108-111}$, and a killed vaccine. The latter took precedent ${ }^{112,113}$ because the prototype killed vaccine $e^{106}$, with its established technology, was easier to license. It was licensed in 1996, following proof of efficacy ${ }^{122}$. (See hepatitis A reviews, refs. 115-117).

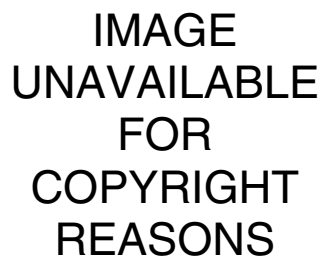

Hepatitis A (artist's rendition). 


\section{Bacterial subunit vaccines}

Meningococcal Vaccines. Invasive bacterial infections have long been an important cause of death and disability. In the late 1950 's, repetitive outbreaks of meningococcal (Neisseria) disease appeared among soldiers on military posts in the US. The military response was to develop an experimental subunit polysaccharide vaccine at Walter Reed ${ }^{118}$. Our program was pioneering and consisted of isolation, purification and definition of capsular polysaccharides of meningococci that were formulated into vaccines and evaluated clinically ${ }^{119}$. Large controlled clinical trials were carried out in Finland ${ }^{120}$ and monovalent group $\mathrm{A}$ and $\mathrm{C}$ vaccines were licensed in 1974 and 1975, respectively. We also received a license for combined $\mathrm{A}$ and $\mathrm{C}$ vaccine and for a polyvalent $\mathrm{A}, \mathrm{C}, \mathrm{Y}$ and $\mathrm{W} 135$ serogroup product.

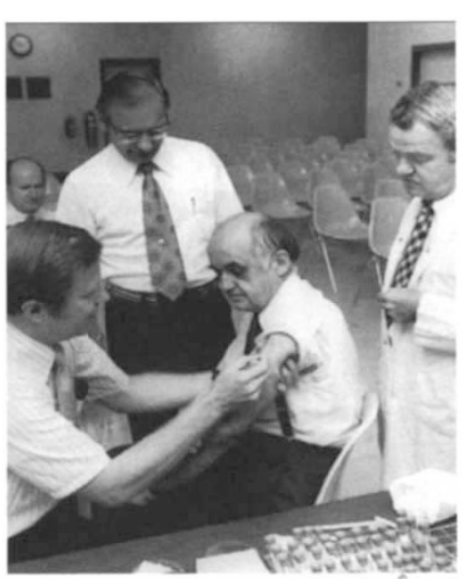

The author-first to receive experimental vaccines.

The author-first to receive experimental vaccines. experimental vaccine was evolved and taken to clinical trial in 1983 (ref. 129). A better engineered vaccine was developed over ensuing years and was licensed in 1989 (ref. 130). The success of the conjugated Haemophilus influenzae $b$ vaccine paved the way for coupled meningococcal and pneumococcal vaccines that will play seminal roles in preventing death and disability in infants in the future.

Respiratory disease vaccines. Extensive fieldlaboratory investigations were carried out to define the cause and importance of a number of respiratory disease ${ }^{131,132}$. Preparation and clinical testing of vaccines against respiratory syncytial, parainfluenza types 1,2 and 3 , and influenza A \& B viruses plus Mycoplasma pneumoniae in individual and in complex combinations ${ }^{133-138}$ showed great promise. The findings with the Mycoplasma vaccine indicated substantive protective efficacy ${ }^{137}$. This was supported in a study by W. Mogabgab ${ }^{137}$ among 12,000 recruits at Keesler Air Force Base in which there was 43 percent reduction of pneumonia, all causes, and 46 percent reduction in clinical cases of bronchitis, using the vaccine. While important as orienting probes, there was difficulty in achieving acceptably high specific attack rates for the virus infections in field studies and the vaccines were not taken to further development. Although a useful six-valent (serotypes) polysaccharide vac $\mathrm{ne}^{\mathrm{see}} 121$ had been developed and distributed in the mid-1940's, it was scarcely used because of the successful treatment of pneumonias by penicillin and the sulfonamides. The vaccine would have become history had it not been for the efforts of $R$. Austrian ${ }^{4}$ who recognized the shortcomings of antimicrobial therapy and who proceeded to define the prevalence of more than 80 serotypes of pneumococci. Support by the National Institutes of Health allowed Austrian to prepare experimental vaccines of low valency made by a pharmaceutical company that soon abandoned the field. Our interest in Austrian's work arose from our prior studies of meningococci and prompted the isolation and chemical definition of polysaccharides of numerous serotypes. Our own vaccines ${ }^{122}$ and those formulated for Austrian ${ }^{123}$ were found to be protective in clinical studies among gold miners in South Africa. Initially 14-valent ${ }^{124-128}$ and later 23-valent vaccines were licensed in 1977 and 1983, respectively, the latter affording protection against 90 percent of the invasive strains of pneumococci.

Haemophilus Influenzae b Vaccine. A third bacterial invader was Haemophilus influenzae $b$ that caused death and disability from pneumonia and central nervous system disease. Early preparations of polysaccharide vaccine showed promise in clinical trials in older children but the vaccine, like that of the pneumococci and meningococci, was unsuccessful in young children whose immune systems had not yet matured and there seemed to be little interest in bringing it to licensure. At a meeting of polysaccharide vaccine experts in Portugal in the early 1970s, an unsung hero whose identity has faded from memory, made the startling revelation that he could elicit $T$ cell participation in the immune responses against polysaccharides that had been coupled to proteins and could achieve high-level immune responses in infant animals. This started a scramble in a number of laboratories including our own. The problem of appropriate and controlled coupling was to be a major undertaking but a worthy
Respiratory syncytial virus vaccine. A live respiratory syncytial virus vaccine was developed ${ }^{139}$ that gave significant humoral responses in initially seronegative children following parenteral injection. Protection against respiratory syncytial virus is needed in early life and there is no simple means to determine whether and when individual children have lost their maternal antibody that, when present, prevents vaccine takes. A largescale controlled trial was carried out by Mufson and Belshe in West Virginia in 1981-1982 but the attack rate for respiratory syncytial virus disease was too low to provide a definitive evaluation. Promising as it was, because this live parenteral vaccine lacked a determinable age for immunization, it was abandoned.

Rhinoviruses. Probes were made during the 1960 's to discover progress awaited the development of simple technologies for cultivating common cold viruses in the laboratory ${ }^{140}$. Three independent and important discoveries of cold viruses were made by 1961 (refs. 141-143) and the field was further lifted by the breakthrough discovery that the coryzaviruses ${ }^{143}$ could be recovered and grown readily in the newly developed WI-38 human diploid cell strain with distinctive cytopathic changes. Characterization of the biologic and physical properties of the three groups of agents $^{140,144,145}$ revealed a common species relationship and 54 agents were named the rhinoviruses ${ }^{148}$. The rhinoviruses were clearly defined as a prominent cause for respiratory illness in man $^{141}$. Epidemiologic studies showed that persistent immunity followed recovery from individual infection $\mathrm{s}^{149}$ but that the large number of diverse serotypes would explain the repetitive occurrence of clinical colds in single individuals. Vaccine development was not pursued beyond a failed attempt ${ }^{150}$ to immunize by oral feeding of live virus in enteric-coated capsules. and define the etiology of the common cold, but substantive distinct serotypes ${ }^{140,144,146,147}$ were defined. By agreement, the 


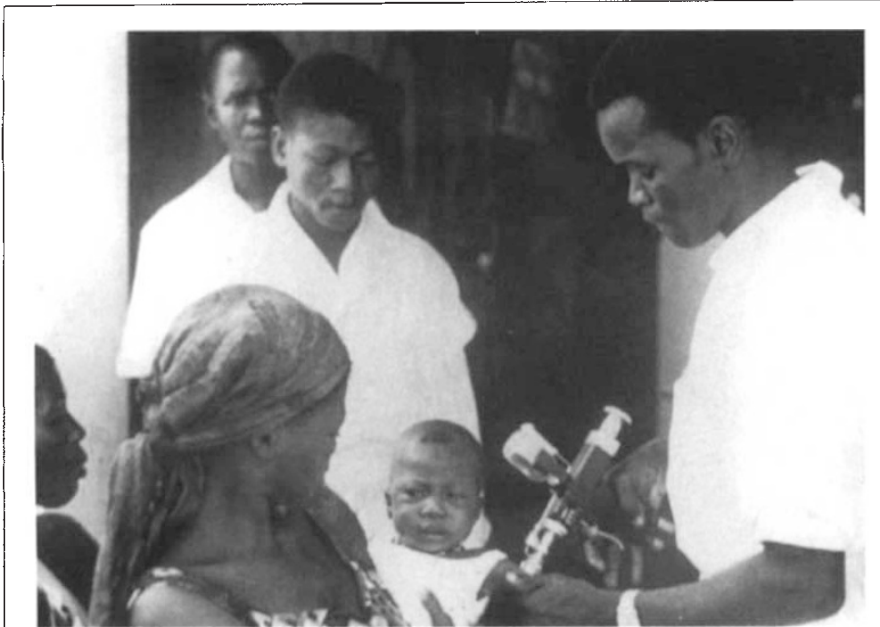

Jet gun administration of vaccine.

\section{Heritage and future}

The heritage of twentieth century evolution and development of vaccines is revealed in the fruits of their application, providing both societal and economic benefits to the peoples of the world. Application of vaccines in the developed nations haslong reduced previously important diseases to insignificant occurrences. In the US, measles, mumps, and rubella have become inconsequential and the chicken pox and pneumonia and CNS disease caused by varicella and Haemophilus influenzae $b$ may soon go the same way. The greater good in preventing death and disability will be seen in developing nations where so much can be achieved for so little.

Worldwide vaccine usage was greatly increased by the creation of the Expanded Program for Immunization of the World Health Organization (WHO) in 1971 (ref. 151) and in its renewal ${ }^{152}$ in 1990 by the Declaration of New York followed by the creation of the Global Program for Vaccines (GPV) and the Children's Vaccine Initiative (CVI) ${ }^{151}$.

As of now, three million deaths are prevented worldwide each year by vaccines, one million alone through vaccination against measles. The annual economic payoff in the US from use of MMR vaccine is $\$ 5.1$ billion $^{60}$. Even greater benefit comes with total eradication such as was accomplished for smallpox in 1997, with worldwide present savings of $\$ 1.1$ billion per year. Eradication of poliovirus is anticipated by the year 2000 with expected savings of three billion dollars per year. Measles eradication may occur early in the twenty-first century. Hepatitis B virus has but a single serotype and ultimately can be eradicated. But Hepatitis B vaccine has been underutilized (although 75 nations have begun universal immunization of their newborn).

The world in the $21^{\text {st }}$ century will be faced with old and new threats from emergence of new disease agents, the development of resistance to organisms controlled previously by antimicrobials and by possible proliferation of biologic warfare and terrorism with disease producing agents. These are the challenges of the 21 st century that will need to rely mainly, for the foreseeable future, on the technologies of the $20^{\text {th }}$ century. Vaccines are a cheap solution to problems of infectious diseases. Their affordability to developing nations must depend, in part at least, on the generosity of donors.
1. Plotkin, M.S.L.S. \& Plotki n, S.A. Vaccines. (eds. Plotkin S.A. \& Mortimer, E.A.) Ch. 1, 1-7 (W.B. Saunders, Philadelphia, 1988).

2. Jenner, E. An Inquiry into the Causes and Effects of the Variolae Vaccinae (Low, London, 1798).

3. Enders, J.F., Weller, T.H. \& Robbins, F.C. Science 109, 85-87 (1949).

4. Austrian, R. Rev. Infect. Dis. 3, 183-189 (1981).

5. Hilleman, M.R. J. Inf. Dis. 76, 96-114 (1945).

6. Sabin A.B. I. Amer. Med. Assoc. 122, 478-486 (1943).

7. Hilleman, M.R. \& Nigg, C. J. Immunol. 53, 201-208 (1946).

8. Hilleman, M.R. \& Nigg, C. I. Immunol. 59, 349-364 (1948).

9. Hilleman, M.R., Buescher, E.L. \& Smadel, J. E. Pub. Hith. Repts. 66, 1195-1203 (1951).

10. Hilleman, M.R., Mason, R.P. \& Rogers, N.G. Pub. Hith. Repts. 65, 771-777 (1950).

11. Hilleman, M.R., Mason, R.P. \& Buescher, E.L. Proc. Soc. Exper. Biol. Med. 75 829-835 (1950).

12. Hilleman, M.R. \& Horsfall, F.L. J. Immunol. 69, 343-356 (1952).

13. Hilleman, M.R. Ann. Rev. Microbiol. 8, 3111-332 (1954).

14. Hilleman, M.R., Werner, J.H. \& Gauld, R. L. Bull. WHO 8, 613-631 (1953),

15. Webster, R.G. Encyclopedia of Virology. (eds. Webster, R.G. \& Granoff, A.) Vol. 2, 709-727 (Academic Press, New York, 1994).

16. Meyer, H.M., Ir., Hilleman, M.R., Miesse, M.L., Crawford, I. P. \& Bankhead, A.S. Proc. Soc. Exper. Biol. Med. 95, 609-616 (1957).

17. Hilleman, M.R. Military Med. 123, 23-30 (1958).

18. Hilleman, M. R., Flatley, F.J., Anderson, S.A., Luecking, M.L. \& Levinson, D.J. 1. Amer. Med. Assoc. 166, 1134-1140 (1958).

19. Hilleman, M.R., Werner, J. H., Adair, C.V. \& Dreisbach, A. R. Am. J. Hygiene 61, 163-173 (1955).

20. Hilleman, M.R. \& Werner, I.H. Proc. Soc. Exper. Biol. Med. 85, 183-188 (1954)

21. Hilleman, M.R., Werner, J.H., Dascomb, H. E. \& Butler, R.L. Am. J. Publ. Hith. 45, 203-210 (1955).

22. Dascomb, H.E. \& Hilleman, M.R. Am. J. Med. 21, 161-174 (1956).

23. Hilleman, M.R., Werner, J.H., Dascomb, H.E., Butler, R.L. \& Stewart, M.T. Am J. Hygiene 62, 29-43 (1955).

24. Hilleman, M.R., Tousimis, A.J. \& Werner, J.H. Proc. Soc. Exper. Biol. Med. 89 587-593 (1955)

25. Tousimis, A.J., \& Hilleman, M.R. Virology 4, 499-508 (1957)

26. Hilleman, M.R., Werner, J.H. \& Stewart, M.T. Proc. Soc. Exper. Biol. Med. 90 555-562 (1955).

27. Rowe, W.P., Huebner, R.J., Gilmore, L.K., Parrott, R.H. \& Ward, T.G. Proc. Soc Exper. Biol. Med. 84, 570-573 (1953).

28. Enders, J.F. et al. Science 124, 119-120 (1956).

29. Hilleman, M.R., Stallones, R.A., Gauld, R.L., Warfield, M. S. \& Anderson, S.A. Proc. Soc. Exper. Biol. Med. 92, 377-383 (1956).

30. Hilleman, M.R., Warfield, M. S., Anderson, S.A. \& Werner, J.H. J. Amer. Med. Assoc. 163, 4-9 (1957).

31. Stallones, R.A., Hilleman, M.R., Gauld, R.L., Warfield, M.S. \& Anderson, S.A. I Amer. Med. Assoc. 163, 9-15 (1957).

32. Hilleman, M R., Greenberg, J. H., Wartield, M.S., Anderson, S.A. \& Glabere, R.R. A.M.A. Arch. Int. Med. 102, 428-436 (1958),

33. Robbins, F.C. Vaccines. (eds. Plotkin, S.A. \& Mortimer, E.A., Jr.) Ch. 6, 98-114 (Publisher, City, 1988).

34. Enders, J.F., Katz, S.L. \& Holloway, A. New Engl. J. Med. 263, 153-159 (1960)

35. Katz, S.L., Enders, J.F. \& Holloway, A. New Engl. J. Med. 263, 159-161 (1960)

36. Reilly, C.M., Stokes, J., Jr., Buynak, E.B., Goldner, H. \& Hilleman, M.R. New Engl. J. Med. 265, 165-169 (1961).

37. Stokes, J. et al. New Engl. J. Med. 265, 507-513 (1961).

38. Stokes, J., Jr., Weibel, R., Halenda, R., Reilly, C.M. \& Hilleman, M.R. Am. J. Publ. Hith. 52, 29-43 (1962).

39. Hilleman, M.R. et al. Am. J. Publ. Hith. 52, 44-56 (1962).

40. Hughes, W.F., Watanabe, D.H. \& Rubin, H. Avian Dis, 7, 154-165 (1963).

41. Hilleman, M.R. et al. I. Amer. Med. Assoc. 206, 587-590 (1968)

42. Buynak, E.B. \& Hilleman, M.R. Proc. Soc. Exper. Biol. Med. 123, 768-775 (1966).

43. Stokes, J., Ir., Weibel, R.E., Buynak, EB., Whitman, J.E., Jr., \& Hilleman, M.R. Pediatrics 39, 363-371 (1967).

44. Weibel, R.E., Stokes, J. Jr., Buynak, E.B., Whitman, J.E., Jr., \& Hilleman, M.R N. Engl. f. Med. 276, 245-251 (1967).

45. Hilleman, M.R., Weibel, R.E., Buynak, E. B., Stokes, Jr. |r., \& Whitman, J.E. N Engl. J. Med. 276, 252-258 (1967.)

46. Weller, T.H. \& Neva, F.A. Proc. Soc. Exper. Biol. Med. 111, 215-225 (1962)

47. Parkman, P.D., Buescher, E.L. \& Artenstein, M.S. Proc. Soc. Exper. Biol. Med. 111, 225-230 (1962).

48. Buynak, E.B., Larson, V.M., McAleer, W.J., Mascoli, C.C., \& Hilleman, M.R. Amer. /. Dis. Child. 118, 347-354 (1969).

49. Weibel, R.E. et al. /. Amer. Med. Assoc. 205, 554-558 (1968)

50. Buynak, E.B., Hilleman, M.R., Weibel, R.E., \& Stokes, Jr., J. I. Amer. Med. Assoc 204, 195-200 (1968)

51. Hilleman, M.R., Buynak, E.B., Weibel, R.E. \& Stokes, Jr. J. N. Engl. .. Med. 279, 300-303 (1968)

52. Stokes, Ir. J., Weibel, R.E., Buynak, E.B., \& Hilleman, M.R. Symp. Series Immunobiol. Standard. 11, 415-422 (Karger, Basel/New York, 1969).

53. Stokes, Ir.J., Weibel, R.E., Buynak, E.B. \& Hilleman, M.R. Pediatrics. 44 217-224 (1969).

54. Weibel, R.E., Stokes, J.Jr., Buynak, E.B., \& Hilleman, M.R. Amer. /. Dis. Child. 
118, 226-229 (1969).

55. Hilleman, M.R., Buynak, E.B., Whitman, J.E. Jr., Weibel, R.E., \& Stokes, J.Jr. Amer. J. Dis. Child. 118, 166-171 (1969).

56. Weibel, R.E., Stokes, J. Jr., Buynak, E.B., Hilleman, M.R., \& Grunmeier, P.W. Pediatrics 37, 913-920 (1966).

57. Kalabus, F., Sansarricq, H., Lambin, P., Proulx, J., \& Hilleman, M.R. Am I. Epidem. 86, 93-111 (1967).

58. Hilleman, M.R. Vaccinia, Vaccination and Vaccinology: Jenner, Pasteur and their successors. (eds. Plotkin, S. \& Fantini, B.) 283-292 (Elsevier, Paris, 1996).

59. Hilleman, M.R. Combination Vaccines. (ed. Ellis, R.W.) (Humana Press, Totowa, $\mathrm{NJ}$, ) in press.

60. Hatziandreu, E.J., Brown, R.F. \& Halpern, M.T. Report to the Centers for Disease Coantrol and Prevention. Cost benefit analysis of the measlesmumps-rubella (MMR) vaccine. (Battelle, Arlington, VA, May 14, 1994).

61. Neff, B.J. et al. Proc. Soc. Exper. Biol. Med. 166, 339-347 (1981).

62. Takahashi, M., Asano, Y., Kamiya, H. \& Baba, K. Microbiol. Sciences 2, 249-254 (1985).

63. Weibel, R.E. et al. N. Engl. J. Med. 310, 1409-1415 (1984).

64. Okazaki, W., Purchase, H.C. \& Burmester, B.R. Avian Dis. 14, 413-429, 1970

65. Hilleman, M.R. Avian Dis. 16, 191-199 (1972).

66. Hilleman, M.R. Viruses, Evolution, and Cancer. Basic Considerations. (eds. Kurstak, E. \& Maramorosch, K.) 549-560 (Academic Press, New York, 1974).

67. Salk, J. \& Drucker, !. Vaccines. (eds. Plotkin, S.A. \& Mortimer, E.A.) Ch. 8, 158-181 (W.B. Saunders, Philadelphia, 1988).

68. Meinick, J.L. Vaccines. (eds. Plotkin, S.A. \& Mortimer, E.A.) Ch. 7, 115-157 (W.B. Saunders, Philadelphia, 1988)

69. Hilleman, M.R. et al. Acad. Med. N. J. Special Bull., 6 (3), 1-31 (1960).

70. Charney, I., Tytell, A A., Machlowitz, R.A. \& Hilleman, M.R. J. Amer. Med. Assoc. 177, 591-595 (1961).

71. Hull, R.N.Virology Monographs. (eds. Gard, S., Hallauer, C., \& Meyer, K.F.) 2-66 (Springer-Verlag, New York, 1968).

72. Sweet, B.H. \& Hilleman, M.R. Second International Conference on Live Poliovirus Vaccines, Pan American Health Organization and the W.H.O., Washington, DC, 6-7 June, 1960, pp 79-85.

73. Sweet, B.H. \& Hilleman, M.R. Proc. Soc. Exper. Biol. Med. 105, 420-427 (1960).

74. Hilleman, M.R. Dev. Biol. Stand. (1998), in press.

75. Girardi, A.J., Sweet, B.H., Slotnick, V.B. \& Hilleman, M.R. Proc. Soc. Exper Biol Med 109, 649-660 (1962)

76. Girardi, A.J., Sweet, B.H., \& Hilleman, M.R. Proc. Soc. Exper. Biol. Med. 112, 662-667 (1963).

77. Goldner, H., Girardi, A.J., Larson, V.M., \& Hilleman, M.R. Proc. Soc. Exper. Biol. Med. 117, 851-857 (1964).

78. Levine, A. Adv. Cancer Res. 65, 141-148 (1994).

79. Butel, I.S. Encyclopedia of Virology. (eds. Webster, R.G. \& Granoff, A.) 3 , 1322-1329 (Harcourt Brace \& Co., New York, 1994)

80. Hilleman, M.R. et al. Amer. I. Med. Sci. 270, 401-404 (1975).

81. Buynak, E.B. et al. J. Amer. Med. Assoc. 235, 2832-2834 (1976).

82. Hilleman, M.R. et al. Viral Hepatitis. (eds. Vyas, G.N., Cohen, S.N. \& Schmid, R.) 525-537 (Franklin Institute Press, Philadelphia, 1978)

83. Hilleman, M.R., Buynak, E.B., McAleer, W.J., McLean A.A., \& Tytell, A.A. Virus and the Liver. (eds. Bianchi, L., Gerok, W., Sickinger, K. \& Stalder, G.A.) 389-395 (MTP Press Ltd., London., 1979).

84. Hilleman, M.R. et al. Viral Hepatitis. 1981 International Symposium. (eds. Szmuness, W., Alter, H. \& J. Maynard, J.) 385-397 (The Franklin Institute Press Philadelphia, 1982).

85. Szmuness, W. Stevens, C.E., Zang, E.A., Harley, E.J., \& Kellner, A. A. Hepatology 1, 377-385 (1981).

86. Valenzuela, P., Medina, A., Rutter, W.J., Ammerer, G. \& Hall, B.D. Nature 298, 347-350 (1982).

87. McAleer, W.J. et al. Nature $307,178-180$ (1984)

88. Hilleman, M.R. Infection 15, 2-6 (1987).

89. Hilleman, M.R., Weibel, R.E. \& Scolnick, E.M. J. Hong Kong Med. Assoc. 37, 75-85 (1985).

90. Hilleman, M.R. Advances in Exper. Med. \& Biol. series (eds. Petricciani, J.C., Hopps, H.E. \& Chapple, P.J.) 47-58 (Plenum Publishing, New York, 1979).

91. McAleer, W.J. et al. J. Virol. Meth. 7, 263-271 (1983).

92. McAleer, W.J. et al. Proc. Soc. Exper. Biol. Med. 175, 314-319 (1984).

93. Hilleman, M.R. et al. Viral Hepatitis and Liver Disease. (eds. Vyas, G.N., Dienstag, I. \& Hoofnagle, J.) 307-314 (Grune \& Stratton, Orlando, Florida, 1984).

94. Hilleman, M.R. J. Med. Virol. 31, 5-12 (1990).

95. Hilleman, M.R. Hepatitis B Vaccines in Clinical Practice. (ed. Ellis, R.W.) Ch. 2, 17-39 (Marcel Dekker, New York, 1979).

96. Hilleman, M.R. Microbe Hunters, Then and Now. (eds. Koprowski, H. \& Oldstone, M.B.A.) Ch. 16, 221-233 (Medi-Ed Press, Bloomington, IL, 1996).

97. Hilleman, M.R. Vaccinia, Vaccination and Vaccinology: Jenner, Pasteur and their successors. (eds.Plotkin, S. \& Fantini, B.) 199-209 (Elsevier, Paris, 1996).

98. Mascoli, C.C. et al. Proc. Soc. Exper. Biol. Med. 142, 276-282 (1973).

99. Provost, P.J., Ittensohn, O.L., Villarejos, V.M., Arguedas G., I.A. \& Hilleman, M.R. Proc. Soc. Exper. Biol. Med. 142, 1257-1267 (1973).

100. Deinhardt, F., Holmes, A.W., Capps, R.B. \& Popper, H. J. Exper. Med. 125 673-678 (1967).
101. Simons, J.N. et al. Proc. Natl. Acad. Sci. USA. 92, 3401-3405 (1995).

102. Hilleman, M.R. et al. Dev. Biol. Stand. 30, 383-389 (1975).

103. Hilleman, M.R. et al. Dev. Biol. Stand. 30, 418-424 (1975).

104.Provost, P.J. et al. Proc. Soc. Exper. Biol. Med. 148, 532-539 (1975).

105. Provost, P.J. et al. Amer. J. Med. Sci. 270, 87-92 (1975).

106. Provost, P. \& Hilleman, M.R. Proc. Soc. Exper. Biol. Med. 159, 201-203 (1978).

107. Provost, P.J. \& Hilleman, M.R. Proc. Soc. Exper. Biol. Med. 160, 213-221 (1979).

108. Provost. P.J. et al. Proc. Soc. Exper. Biol. Med. 170, 8-14 (1982).

109. Provost, P.J. et al. J. Med. Virol. 20, 165-175 (1986).

110. Midthun, K. et al. / Infect Dis 163, 735-739 (1991).

111. Midthun, K. et al. J Infect Dis 327, 453-457 (1992).

112. Provost, P.J. et al. Med. Virol. 19, 23-31 (1986).

113. Lewis, J.A. et al. Viral Hepatitis and Liver Disease. (eds. Hollinger, F.B., Lemon, S.M. \& Margolis, H.) 94-97 (Williams \& Wilkins, Baltimore, 1991).

114. Werzberger, A. et al. N. Engl. J. Med. 327, 453-457 (1992).

115. Hilleman, M.R. J. Hepatology 18, \$5-\$10 (1993).

116. Hilleman, M.R. Proceedings of the Symposium on Highlights of Viral Hepatitis and Hepatocellular Carcinoma Research, 1992 (eds. Oon, C-J. \& Aw, S-E.) 86-95 (Harper Press (Pte) Ltd, Singapore, 1993).

117. Hilleman, M.R. et al. J. Gastroenterol. Hepatol. 8, S21-S26 (1993)

118. Gotschlich, E.C., Liu, T.Y. \& Artenstein, M.S. J. Exper. Med. 129, 1349-1365 (1969)

119. Weibel, R.E. et al. Proc. Soc. Exper. biol. Med. 153, 436-440 (1976)

120.Lepow, M.L. Vaccines. 2nd Ed. (eds. Plotkin S.A. \& Mortimer, E.A. Jr.) Ch. 17, 503-515 (W.B. Saunders, Philadelphia, 1994).

121. Fedson, D.S. Vaccines. (eds. Plotkin S.A. \& Mortimer, E.A.) Ch. 13, 271-299 (W.B. Saunders, Philadelphia, 1988)

122. Smit, P., Oberholzer, D., Hayden-Smith, S., Koornhof, H.J. \& Hilleman, M.R. J. Amer. Med. Assoc. 238, 2613-2616 (1977).

123. Austrian, R. et al. Trans. Assoc. Amer. Physicians. 89, 184-189 (1976).

124. Hilleman, M.R. Bull. WHO 55 (S2), 31-33 (1977).

125. Hilleman, M.R., McLean, A.A., Vella, P.P., Weibel, R.E. \& Woodhour, A.F. Bull. WHO 56, 371-375 (1978).

126. Hilleman, M.R., McLean, A.A., Vella, P.P., Weibel, R.E. \& Woodhour, A.F. J. Infection 1, 1-16 (1979).

127. Hilleman, M.R. et at. Pneumonia and Pneumococcal infections. (eds. Lambert, H.P. \& Caldwell, A.D.S.) Royal Soc. Med. Intl. Congr. \& Symp. Series 27, 67-85 (Academic Press, London, 1980).

128. Hilleman, M.R. et al. Rev. Infect. Dis. 3, S3I-S42 (1981).

129. Tai, I.Y. et al. Proc. Soc. Exper. Biol. Med. 184, 154-161 (1987).

130. Santosham, M. Wolff, M., Reid, R, et al. N. Engl. J. Med. 324, 1767-1772 (1991).

131. Hilleman, M.R. et al. J. Amer. Med. Assoc. 180, 445-453 (1962)..

132. Hilleman, M. R. Am. Rev. Resp. Dis. 87, 165-180 (1963)

133. Woodhour, A.F. et al. Am. Rev. Resp. Dis. 94, 350-361 (1966).

134. Weibel, R.E., Stokes, J. Ir., Leagus, M.B., Mascoli, C.C. \& Hilleman, M.R. Am. Rev, Resp. Dis. 94, 362-379 (1966)

135. Leagus, M.B., Weibel, R.E., Mascoli, C.C., Stokes, J. Jr. \& Hilleman, M.R. Am. Rev. Resp. Dis., 95, 838-844 (1967).

136. Hilleman, M.R. et al. PAHO Sci. Publ. 147, 141-154 (Nov., 1966).

137. Weibel, R.E. et al. Am. Rev. Resp. Dis. 96, 724-739 (1967).

138. Vella, P.P. et al. Am. Rev. Resp. Dis. 99, 526-541 (1969).

139. Buynak, E.B., Weibel, R.E., McLean, A.A. \& Hilleman, M.R. Proc. Soc. Exper. Biol. Med. 157, 636-642 (1978).

140. Hilleman, M.R. Ergebnisse der Mikrobiologie Immunitatsforschun und Experimentellen Therapie, Springer-Verlag, Heidelberg, 41, 1-22 (1967).

141. Pelon, W. Amer. J. Hygiene. 73, 36-54 (1961).

142. Tyrrell, D.A.J. \& Bynoe, M.L. Brit. Med. J. 5223, 393-397 (1961).

143. Hamparian, V.V., Ketler, A. \& Hilleman, M.R. Proc. Soc. Exper. Biol. Med. 103, 444-453 (1961).

144. Ketler, A. Hamparian, V.V. \& Hilleman, M.R. Proc. Soc. Exper. Biol. Med. 110 821-831 (1962).

145. Hamparian, V.V., Ketler, A. \& Hilleman, M.R. Am. Rev. Resp. Dis. 88, 269-273 (1963).

146. Hamparian, V.V., Leagus, M.B., \& Hilleman, M.R. Proc. Soc, Exper. Biol. Med. $116,976-984$ (1964).

147. Mascoli, C.C., Leagus, M.B., Hilleman, M.R., Weibel, R.E., \& Stokes, J. Jr. Proc Soc. Exper. Biol. Med. 124, 845-850 (1967).

148. Tyrrell, D.A.J. \& Chanock, R.M. Science 141, 152-153 (1963),

149. Hamparian, V.V., Leagus, M.B., \& Hilleman, M.R., Stokes, J., Ir. Proc. Soc. Exper. Biol. Med. 117, 469-476 (1964).

150. Mascoli, C.C. et al. Proc. Soc. Exper. Biol. Med. 121, 1264-1268 (1966)

151. The World Health Report 1996, World Health Organization, Geneva, 137 pages (1996).

152. The CVI Strategic Plan. Managing Opportunity and Change: A Vision of Vaccination for the 21st Century. Children's Vaccine Initiative, W.H.O., Geneva (1997).

Merck Institute for Therapeutic Research

Merck Research Laboratories

West Point, Pennsylvania 19486 U.S.A. 